\title{
Goldwork of the Iron Age in 'Barbarian’ Europe
}

\author{
Christiane Eluère \\ Musèe des Antiquités Nationales, St-Germain-en-Laye, France

\begin{abstract}
Archaeological and technological evidence, and texts of classical authors bave made it possible to construct a picture of the art of gold working during the Iron Age in many places in Europe from which no locally written records exist. Influences from oriental and
\end{abstract} \\ mediterranean cultures are discussed.
}

During the Iron Age in Europe, between the 8th century B.C. and the Roman conquest, many changes accompanied the introduction of the use of the new metal. Thus, the peoples of Europe as we know them today were emerging and there is evidence for the first time of extensive use of horses, not just for traction but also for riding. Numerous movements occurred throughout the continent and across the Mediterranean sea. Between 775 and 600 B.C., South Italy and Sicily were colonized by the Greeks, while to the north from 700 to 400 B.C. the Etruscan culture was flourishing. Already, from the beginning of the 1st millenium B.C., contacts between the local population and Phoenicians and Greeks had been developed in South-West Spain, in Andalucia especially, because of its metallic resources and the Tartessos culture was one of the first results of the influence of the Eastern Mediterranean on the Iberian Peninsula. During the 7th and 6th centuries B.C., these contacts with the Oriental and Hellenic worlds extended to Gaul, firstly on its southern coast, through the foundation of Massalia in 600 . As a result, Ionian and Greek products and ideas reached as far north as Burgundy and Southern Germany where, for example, in the large fortified settlement at La Heuneburg, above the Danube, walls of raw clay bricks were erected in accord with Greek architectural practice. Imports of Etruscan wine also helped in the establishment of trade routes between the area south of the Alps and the central European Celtic world which at that time spread from eastern France up to Czechoslovakia. At the same time, the barbarian inhabitants of these areas were trying to enlarge their territories. The Celts had undertaken raids in the direction of Northern Italy in the 4th century B.C., and through Thracia into Greece, as far as Asia Minor (Sack of Delphi in 279). They had also reached the British Isles during the 3 rd century B.C.

At the beginning of the 5 th century B.C., the influence of the eastern Mediterranean peoples began to wane in Europe, while that of the Greek world began to grow. Greek civilization influenced not only countries to the west but also regions to the east bordering on the Black Sea, which became a great cultural crossroad. During the 7 th century, when the Scythians made a short campaign into the Near East, the Greeks were trying to colonize Thracia. As a result their power in that region increased, especially at the end of the 6th century, when Darius and the Persians were defeated on their way to Scythia. The later extension of the Macedonian kingdom and Athens are well known.

The influence which classical peoples such as the Phoenicians, Greeks and Etruscans had upon the barbarian countries of Western, Central and South Eastern Europe is to be perceived in the goldwork of the latter, though there is sometimes great difficulty in establishing it's exact origins. Either the styles were assimilated by local craftsmen, or products and ideas and techniques were imported and partly imitated. Barbarian Europe, which was so rich in metal ores and gold according to writers of this period, seemed to develop a new approach to goldwork during the Iron Age. In the preceding Bronze Age (2000 to 800 B.C.), gold had been used a great deal and sometimes for very heavy jewellery. Now, however, it began to be used for certain defined purposes. It became the privilege of chieftains, whose fascinating burials have been discovered, of gods honoured by sacred offerings, and the hoarding of gold as a store of wealth was carried out. As an extension of this latter use gold coinage appeared later.

\section{Gold Dedicated to Heroes and Princesses}

The abundant use of gold by the 'barbarians', and in particular by the Celts and Scythians, seems to have impressed classical writers.

'In Gaul, there is a great deal of gold which people can easily pick up [from the rivers] ... they hoard large quantities of gold of which not all is for the adornment of women, for men also wear gold rings at the wrists and arms, at the neck heavy gold chains, at fingers precious fingerrings, and even gold 'armours' (Diodore, V).'

"They [Gauls] sleep on a litter of foliage and eat meat principally. They deal mainly with war and crops, and their wealth is cattle and gold, which they can take with them in any circumstance, as they are nomadic' (Polybius, II).

Very few gold objects have been found which have been dated to the beginning of the Iron Age. During the 8th century B.C., a crisis of some kind appears to have arisen, for the rich goldworking centres of the Bronze Age in the Atlantic area suddenly disappeared. Some rare examples are known of the use of gold on heavy iron horsemens' swords, the handles of which are clad with thin gold leaves. At Gomadigen, Baden-Wûrttemberg and in the large cemetery at Hallstatt, Austria, large swords were also decorated with amber, ivory and other precious materials. A gold cup made from a hammered foil decorated with stamped circles has been found in the remains of an old chariot burial of a warrior in Wehringen, Bavaria.

During the 7 th and principally the 6 th century, however, a series of exceptionally rich burials containing gold objects have been excavated in different cultural areas of Europe. In most of these tombs the warriors were buried in a large wooden mortuary house under a huge earthen mound or barrow. The most western group of tombs is located in Celtic country, between Burgundy and Czechoslovakia. More than 50 tombshave been found in which the 
bodies of persons of high social status were laid on a ceremonial fourwheeled chariot. Most of the goldwork known from this region during the 'first Iron Age' (up to 450 B.C.) is derived from these princely tombs or barrows. They were generally erected in the vicinity of large fortified hilltop settlements, as in La Heuneburg, Hohenasperg, in Southern Germany, Le Mont-Lassois in Burgundy and Ütliberg in Switzerland. Such burials were clearly reserved for persons who were important in their communities. The ruler often occupies a central tomb and around him are secondary burials. In 1978-79, at Eberdingen-Hochdorf in Baden-Wûrttemberg such a funeral chamber was carefully excavated and studied (Biel, 1982). Drinking or libation ceremonies seem to have taken place around the dead. In a corner of the chamber a large bronze cauldron with a capacity of 400 litres had been filled with a drink made with honey, at the base of which was found a hammered gold sheet cup decorated with a row of punched circles, which was probably placed above the cauldron and then covered with various materials, traces of which still remain. Along a wall of the chamber, a set of 9 drinking horns decorated with gold stamped strips were also part of the drinking service. In front of the chariot were piled up plates for 9 persons. The remains of a 40 -year old man had been laid on a bronze 'kliné' on the back of which hung his quiver. The man was adorned with numerous gold ornaments. Around his neck, a large hammered sheet ring showed traces of having been deliberately broken, and gold fibulae on his chest were deformed so as to be no longer usable. A belt buckle on a bronze support carried an impressed decoration, like that of the neckring. Bands also

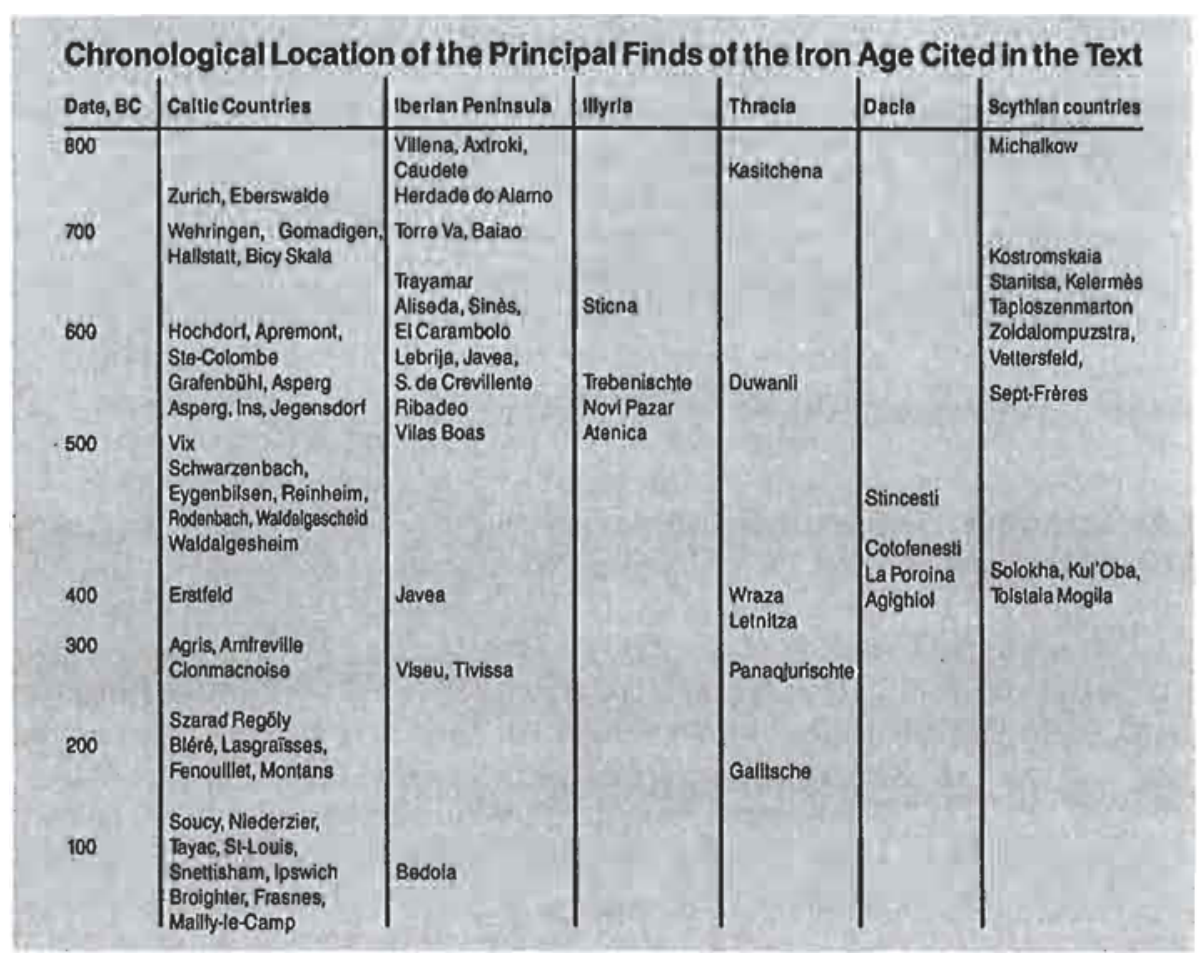

decorated his shoes. An iron dagger with a bronze handle and scabbard found at hisside, is decorated with a detachable gold sheet offering punched motifs, completely different from those on the bronze blade of the weapon.

It seems likely that, apart from the large neckring and the gold cup which could have been used by the man when alive, some of the funeral gold ornaments were manufactured rapidly and on the spot, using the same four punches for the shoe strips, dagger, belt and bracelet, and two other punches for the different drinking horns.

In these aristocratic tombs of the 6th century, the gold objects are often stereotyped. Thus a large neckring has been found in most of them (Bittel, Kimmig, Schieck, 1981). All these neckrings have been made by forming hammered sheet into a circle. There is no evidence of the use of solder. Some are unadorned but many are decorated, with several circular lines made 'au repoussé', between which dots, circles, lozenges, stylized human heads, or, at Hochdorf, stylized horsemen are punched, from the inside or outside, in geometrical patterns. These neckrings have been found from France to Austria and are almost certainly socially symbolic jewels. At Apremont (Haute-Saône), in a chariot burial excavated at the end of the 19th century, two of these bulky neckrings were discovered (Figure 1); besides a latge bronze cauldron there stood a flat cup or a phiale made of one hammered gold piece, with a central omphalos embossed in it. Little button caps and beads were sewn on the man's clothing. Not very far off, in Sainte-Colombe (Côte-d'Or), in Burgundy, another rich individual was buried on an iron chariot, together with two iron axes. He was adorned with a pair of large bracelets made of hammered sheet gold decorated also with repoussé lines and rows of punched cross bars. The ends here are particularly elaborate in comparison with those of other similar finds. Three strips are soldered across them, the central one having first been embossed (Figure 2). A pair of earrings in this tomb also presents some original features. Each earring is constructed from separately fabricated parts, which are soldered together, in what at the time was a new technique.

Another precious product found in these tombs is a type of brocade with fine gold threads, decorating other precious materials occasionally imported from faroff countries. For example, in a tomb at Hochmichele in Southern Germany, traces of silk from the Orient were discovered. At Grafenbühl in Baden-Württemberg, besides traces of gold brocades, other pieces had come from Syria, such as an ivory mirror 
handle and possibly sphynxes carved in ivory with heads of amber and golden capped rivets. During the 5 th century B.C. princes were still buried with their treasures and amongst these products from the Mediterranean are featured more prominently. For example, bronze drinking services from Etruria are normally found in their tombs together with golden objects.

Two attic cups from the funeral treasure of a cremation at Klein Aspergle in Baden-Württemberg, one of which was painted with figures from the middle of the 5thcentury, support an added Celtic ornamentation which consists of a net of openwork gold foil composed of triple leaves (lotus blooms), fixed with tiny bronze nails. In this tomb, besides a bronze cauldron, a wooden cup, a cordoned cist, numerous Mediterranean imports were also found, for example a bronze oenochoe (wine jug) and an Etruscan stamnos (a particular type of wine jar). Of Celtic origin was a pair of gold sheet

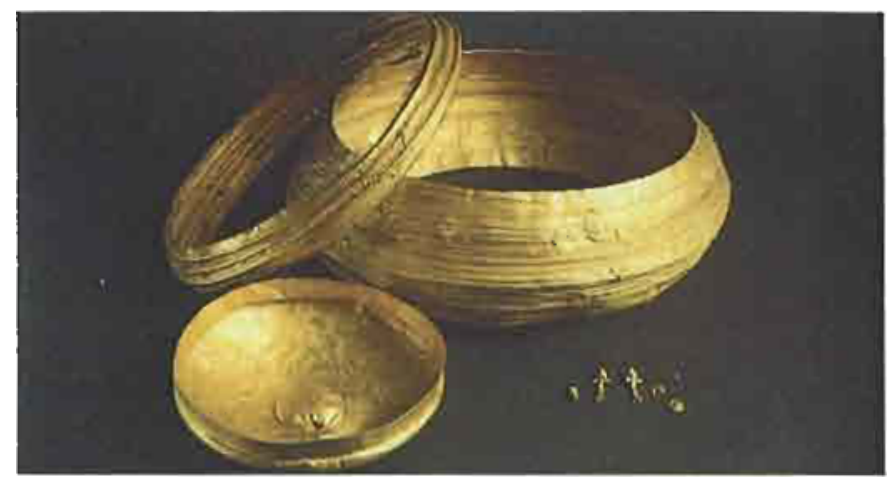

Fig 1. Gold objects from the royal tomb at Apremont (Franche-Comté) comprising two large neckrings of mass $232 \mathrm{gr}$. and $90 \mathrm{gr}$. and external diameters $27 \mathrm{~cm}$ and 20 $\mathrm{cm}$, and also a cup of mass $55 \mathrm{gr}, 14 \mathrm{~cm} 0$. (Musée des Antiquités Nationales, St-Germain-en-Laye) drinking horn mounts decorated with stamped and punched motifs, and carrying rams' heads at their ends. The.gold is supported on a bronze sheet base, and the animal heads are riveted on two iron rods which appear to have been pushed into the bases of the horns. The craftsmen may have been inspired from the Thraco-Scythian rhyta (or drinking hom).

Tombs of Celtic rulers of the 5 th and the beginning of the 4 th centuries B.C. have also been found in other regions such as the Rheinland and Champagne, and this seems to reflect a geographical shift in the centres of Celtic power, with the earlier centres disappearing. In this period, the 'Second Iron Age', changes in burial customs have been found. At Schwarzenbach, a tomb of that period contained a wooden (lignit) cup or bowl decorated by the application of gold foil with a net of openwork gold (Figure 3), similar to that found in the cups of Klein Aspergle. It was probably made in several pieces and bonded together with glue. Small holes indicate, however, that thin nails were also used in its assembly. In this tomb were also found little plaques in the form of human masks, probably made by stamping the foil on a form. Gold openwork made in an impressed and ajorcé cut foil has also been found on drinking hornsfrom tombs at Eygenbilsen (Limburg), Walldalgescheid in Rhineland. Several tombs of warriors buried on their two-wheeled fighting wagons at Suippes, at La Gorge-Meillet and other sites in Champagne have also provided gold jewels, mainly simple bracelets in the form of hammered bars and bootshaped earrings decorated with repoussé dots and lines. Gold objects have not been found in the same abundance in these warriors' tombs as in those of their predecessors of the First Iron Age, who were really considered as kings.

Besides being found in the graves of kings and heroes, gold has also been recovered from the burial sites of some very rich women and other persons. At Schöckingen (BadenWürttemberg) in a 6th-century tomb, a 25-year old woman had a kind of coif which adorned her face. It was held in place with 9 gold rings and 6 bronze pins with bulky heads of sheet gold decorated with repoussé and punched motifs. She was also wearing coral beads from the Mediterranean and, on each arm, three bracelets made in gold bands with repoussé line decorations. But the most impressive of these 'female' tombs is probably that in Burgundy, of the Vix princess, dated from the early 5 th century B.C. It contained a huge bronze wine crater (or mixing vase) of Mediterranean origin (Southern Italy?), $1.62 \mathrm{~m}$ high, with a mass of $200 \mathrm{~kg}$ when empty, and a capacity of 1250 litres. Nearby were a silver phiale with a gold clad omphalos and Etruscan bronze vessels including a wine jug, basins and a black figure-painted attic cup. The setting brings to mind the story told

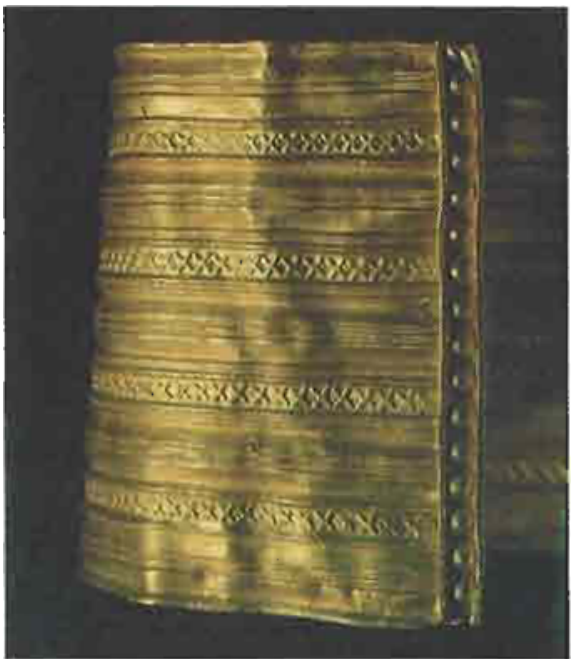

Fig. 2 Detail of a bracelet from the Sainte-Colombe (Burgundy) burial, mass63gr. The repoussé horizontal lines have been stretched from the outside, as well as the frame along the punched crossbars rows. On the right there are traces of part smelting of the metal, which occur in the soldering of the vertical end bars. (Musée des Antiquités Nationales, St-Germain-en-Laye)

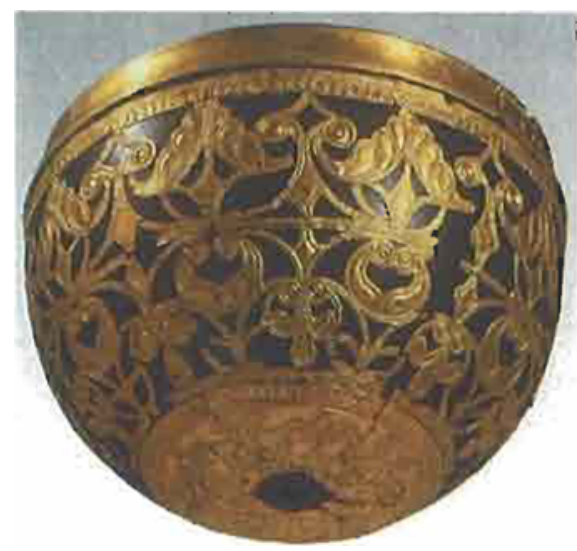


by Herodotus (5th century B.C.) about Croesus, when he was concluding a pact with the Iacedemonians. The latter wanted to make him a present and had a bronze crater made for him, which was so large that it could take the contents of 30 amphorae. Unfortunately the crater did not reach Sardis and must have been stolen or sold during the voyage, the sailors having heard that in the meantime Croesus had been defeated. The Vix crater was probably a similar present. The buried princess lay on a chariot adorned with bronze jewels. Near the skull was a heavy gold neckring or diadem (480 grams) with large, almost spherical "buffer" (or expanded) ends decorated with winged horses leaning against a lion's foot, probably soldered to the body of the ring which was made of thick rolled and soldered gold sheet. The buffer ends have flat discs soldered to their extremities which have been decorated by the punching on them of circular patterns. The same punches have been used for these terminal discs and for the decoration of the upper parts of the spheres and the lion's feet with arcs, crossed bars and circles.

In other tombs from the Rhineland, in Reinheim, Bad Dürkheim, Waldalgesheim, a large series of imported bronze vessels are associated with gold neck- or arm-rings. These are hollow tubes decorated on their outer sides either by repoussé or more frequently by the joining to them of separate parts, such as buffer ends. At Reinheim, a gilded bronze flagon with a spout was found together with a gold torc and bracelets adorned with imaginary semi-human heads. At Waldalgesheim, the jewellery found is florally decorated in a style which was exported to Italy - a gold torc in this style was found at the Filotrano cemetery.

At the Eastern end of the Celtic territory, related goldwork has been found, including stamped gold sheet belt plates in the funeral cave at Bicy Skala, Moravia, (8th-7th centuries B.C.), earrings and diadems in the Slovenian cemetery at Sticna, and decorative plaques at Chlum in Bohemia (Sth-4th centuries B.C.).

Some important findsin Illyrian territory reflect not only Celtic features but also imported Greek and local traditions. They have come from the great tombs at Trebenischte in Macedonia and Novi Pazar and Atenica in Serbia, which date from the beginning of the 5th century B.C. At Atenica, a prince and a princess were found buried in two barrows. It is characteristic that among the grave finds were some of Greek origin like pendants of embossed gold foil in the shape of bees. At Trebenischte, near Ohrid, excavation of four tombs has uncovered much goldwork, and in particular four funeral gold masks made of embossed and hammered gold foil, one of which has a decorated border stamped with braid motifs. These masks appear to reflect a blending of Greek and Central European traditions. A bronze sheet mask, already known from acremation site of the 7 th century at Klein-Klein, Styria is similar, and the big stone statue of a warrior at Hirschlanden, Southern Germany, also seems to wear such a mask, as well as a symbolic large gold neckring of the First Iron Age Celtic chiefs. However, at Trebenischte, Greek influence was strong, especially in the gold sheet sandals and gloves decorated with the Medusa and sphynxes, as well as sketchy representations of the hand and fingers, vases and drinking horns in silver. Some items were possibly Greek imports, such as the bronze wine crater, tripods, jewels with gold filigree, silver fibulae and ceramics. At Novi Pazar a wooden chest was found which contained funeral treasures, probably derived from an Iron Age barrow on which a church had been later erected. In addition to the chest, two Greek ceramic vases, (an Olpe and a Kylix), and seven imported metallic vessels, were uncovered. The chest contained precious metal objectsonly, though it is probable that it originally also contained valuable materials such as leather clothes, of which very tiny traces were found. The precious metal objects included numerous large gold plaques, round pectorals of thick sheet gold with a rosette in the centre and a double concentric plait (diameter $21.5 \mathrm{~cm}$ ), rectangular shaped foils, parts of a suit of armour, large semi-circular plaques with pleated borders for fixing great girdles in hammered gold sheet, ending in a large oval plaque, embossed and incised or decorated with repoussé dots $(80 \mathrm{~cm}$ length and 15 $\mathrm{cm}$ width). These are discoloured on the back, owing to contact with the bronze and leather of the belt. This treasure at Novi Pazar may have been the equipment of three individuals since it includes also 3 pairs of round pectorals, 3 semi-circular plates, 2 girdles, 4 silver Illyrian double pins and 2 pairs of gold fibulae. It is perhaps significant in so far as the funeral rites are concerned that these gold and silver ornaments were placed outside the cremation pyre and separate from the imported ware, since in Grafenbühl, the presents from the South and Near East were also placed apart. Later too, the Dacian silver treasures were put at the border of the barrows. At Novi Pazar there were no weapons. Their absence does not mean that the buried persons were women, since it is possible that they were burnt with the dead on the pyre.

Among the Thracians, who were 'the strongest and most courageous tribes from Europe' and who impressed the Greeks especially by their belief in immortality, the kings who maintained close relations with the Hellenic world were also priests. As early as the 3 rd century B.C., and possibly earlier, artists existed in the royal courts, whose art displayed Greek, Persian and Scythian influences, as well as a political independence. Herodotus described the Thracians as the 'richest people of the world after the Indians', and their goldwork reflects this.

A large number of princely Thracian burials took place from the end of the 6th century and during the 5 th century B.C. in south Bulgaria, in the royal necropolis at Duwanli, and their excavation has yielded goldwork with mixed Hellenic and local features. The oldest tombs were female burials and they are also the richest. At Muschowitza, Arabadhijska and Kukowa, large pectorals, neckrings and massive bracelets are said to have come from Greek workshops erected on the spot. A series of earrings exists made of a cast spiral with pyramidal ends covered with granulation like those of other circular pendants. Generally a silver phiale was part of the grave 
treasures. At Kukowa, a silver amphora had certainly been made by an achemenid goldsmith. However, some embossed pectorals and massive bracelets with stylized animal heads at their ends are local productions. In the Baschowa barrow, a gold pectoral with a lion figure made in repoussé was local work copied from achemenid models. The gilded silver jug and rhyton with the forequarters of a horse carries a Greek inscription and is typical of Greek products modified by Persian influence (Figure 4).

In a later barrow, at Wraza, Mogilanska, dated around 380 to 350 B.C., burial sites have yielded rich material. A woman was found still adorned with gold earrings and a crown of hellenistic type. Richly ornamented horses were buried with the funeral chariot. This tomb also contained various metallic vessels, however the most remarkable is a cnemid (or warrior leg cover) $46 \mathrm{~cm}$ high, made of hammered silver sheet and plated with gold foil on the reliefs produced by chisel work. Hair and eyebrows on the Gorgona mask (Figure 5) again reflect here Greek influence. A silver phiale bears the name of the Thracian king Kotys followed by that of the craftsman Etbeoy. At the end of the 4th century B.C., silver became more used in vessels, jewels, and horse ornaments though it was sometimes gilded.

When speaking about the expedition of Darius against the Scythians, Herodotus described the inhabitants of Dacian territory to the north as the 'bravest and most upright among the Thracians'. A cremation at Agighiol (Rumania) contained a silver cnemid decorated with a mythical composition, embodying a woman's head, a horseman and an imaginary animal. Another - gold clad - features, as do finds in Wraza, gold bands on the face, probably simulating tattoo marks, and a conical, partly gold clad, silver helmet, with apotropaic (defence against the devils) eyes on the visor, and a horseman on the carcovers (Figure 6), some silver vessels, among which are three phiales, and finally gold embossed sheets representing in a striking way a running deer, in the animal style. On the other side of the Black Sea the Scythians were well endowed with gold. Herodotus relates as follows the legend of the creation of the first Scythian dynasty:

"Three brothers, while they still ruled the land, ... there fell from the sky four implements all of gold: a plough, a yoke, a battle axe and a drinking cup. The eldest of the brothers perceived them first and approached to pick them up. As he came near, the gold took fire and blazed. The gold rejected both the eldest and the second eldest brother. The youngest brother approached and immediately the flames were extinguished, so he picked up the gold and carried it to his home. Then the two elder brothers agreed together and made the whole kingdom over to the youngest born'.

The aristocratic character of gold received great emphasis:

'The royal Scythians guard the sacred gold with most special care. Year by year [they] offer great sacrifices in its honour' (Herodotus, Persian Wars, 7).

The Scythians' contact with the Near East is reflected in their art of the late 7 th century, with its animal style. The great kurgans of these nomad kings, whose long and complex burial rites are described by Herodotus and which, according to him, of ten involved the sacrifice of servants, wives and hundreds of horses, appeared around this period. A large repoussé sheet gold plaque, the gold stag from Kostromskaia Stanitza $(31.7 \mathrm{~cm}$ in length)(Figure
Fig. 4 Silver rhyton with gold plated decoration, from the Baschowa barrow at Duwanli (Thracia); $20.6 \mathrm{~cm}$ high. (Archaeological Museum, Plowdis)

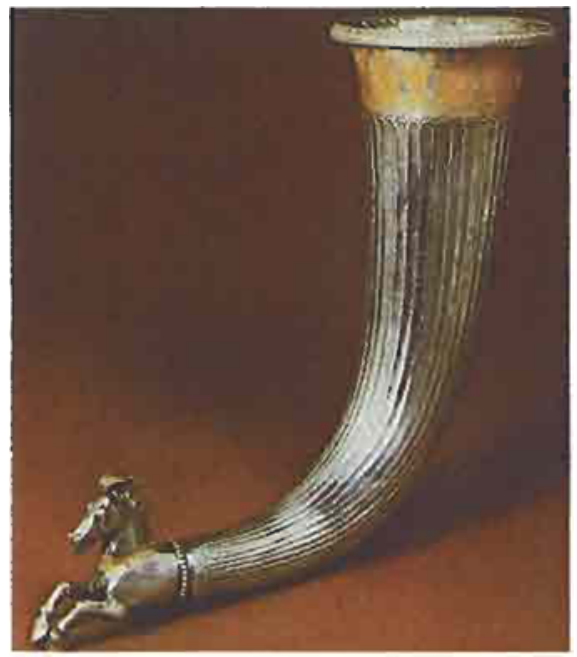

Fig. 5 Detail of the top of the Wraza cnemid in silver and plated gold; 46 cin total height. (Museum of Wraza)

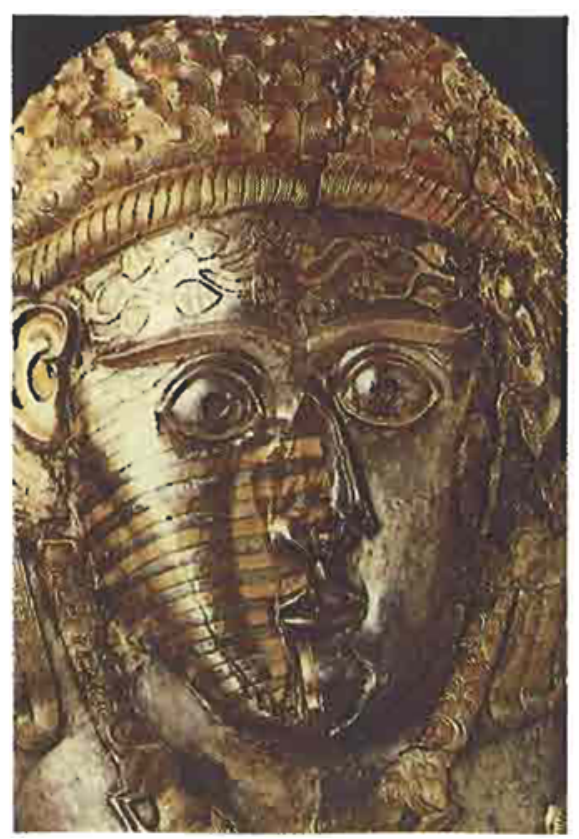

Fig. 6 Helmet from Agighiol (Dacia) in silver and plated gold; $27 \mathrm{~cm}$ high. (National Museum, Bucharest)

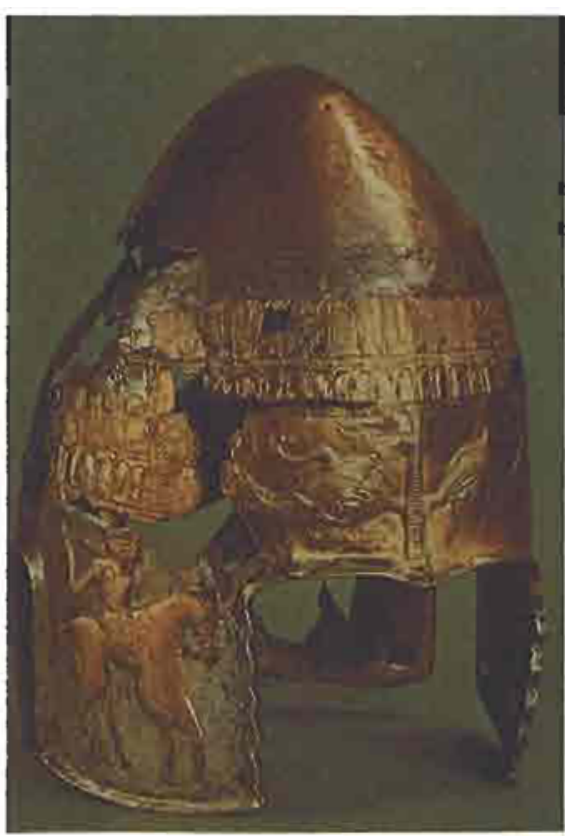



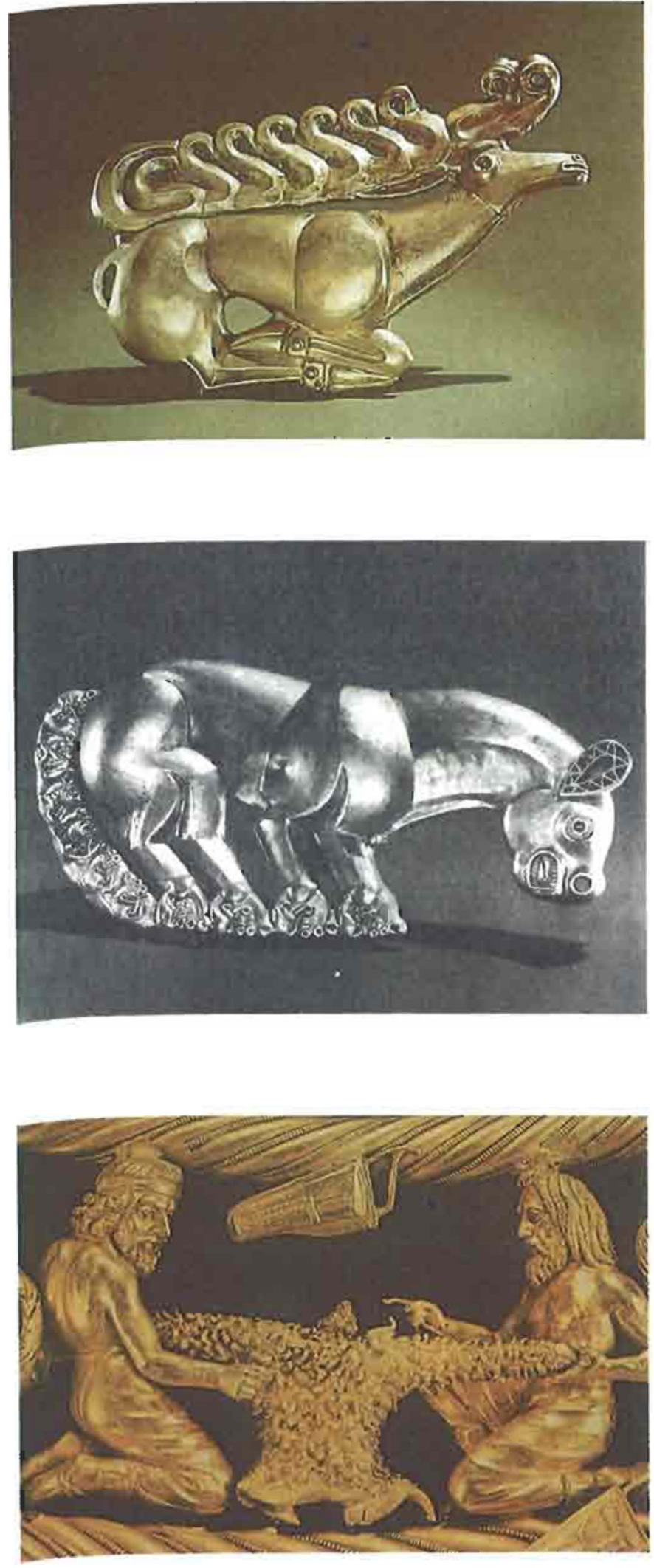

7) was found lying on an iron shield that it must have originally decorated. The stag was one of the most popular Scythian motifs and possibly one of their totems. The bevelled surface suggests that this style was developed in some carved material such as wood. An extraordinary gold panther was found in another of these ancient royal tombs, at Kelermes, in North Caucasus on which a combination (see Figure 8) of Near Eastern and Scythian motifs has also been encountered, the object being also decorated with inlays of glass paste and stone $(32.6 \mathrm{~cm}$ in length). Some elements were also soldered, such as the panther's ear. 'These plaques were hung on the shields they decorated. Other plaques display little peripheral holes which enabled them to be attached with bronze nails. Thus a gorytus (quiver) at Kelermes, decorated with a rectangular gold plaque, the surface of which is divided by repoussé lines, was attached in this way. In each area enclosed by the repoussé lines, a stag is stamped, and its borders are decorated with little stamped panthers. A circular silver mirror, from the same tomb, is covered on its back by eight triangular pieces of gold foil applied to the support and fixed by narrow radiant silver bands. It is also decorated with Near Eastern motifs (lions, trees) and Scythian themes. This piece is considered to have possibly been made by Scythian workers following Ionian examples. Greek settlements appeared on the northern shore of the Black Sea at the end of the 7 th century, and Greek influence often seems evident in Scythian goldwork although there is the possibility of a local craft existing to provide jewellery to be traded with the Mediterranean peoples who were very keen on representations of Scythians, their daily life and their mythology. The famous Kul'Oba kurgan, near Kertch, was the burial place of the Bosporan nobility. Found in this tomb were many rich objects of 'Greek' workmanship, such as the famous gold bottle decorated with Scythians, and pendants decorated with the head of Athena and inspired by the statue at the Parthenon. At Tolstaia Mogila, the greatest discovery so far is a gold pectoral of magnificent workmanship. Its decoration includes meticulously detailed figures of Scythians and animals individually cast and soldered onto the frame in twisted bars bordering floral motifs in soldered wires. Two Scythians are shown making a shirt (Figure 9), another is milking a ewe. They are shown in the midst of their horses, cows, goats and sheep, while nearby are creatures ranging from birds and grasshoppers to griffins savagely tearing at horses. The wealth of the Scythians was well known. Strabo (book XI) writing about the peoples of the Caucasus, near the legendary Colchis, says

Fig. 7 (top) Stag from Kostromskaia Stanitza (Caucasus); $31.7 \mathrm{~cm}$ length and 634 gr. mass. (Ermitage, Leningrad)

Fig. 8 (middle) Panther from Kelermes, barrow No 4 (Caucasus): $32.6 \mathrm{~cm}$ length: mass $734.9 \mathrm{gr}$. and containing glass and amber inlays. (Ermitage, Lening rad)

Fig. 9 (bottom) Detail of the pectoral from Tolstaia Mogila (Ukraine); central scene of men sewing with a curved needle a skirt from a sheep skin. The legend of the "Golden Fleece" has been connected to this scene. (Museum Kiev) 
'the corrents of their country carry gold which they collect by building perforated troughs, through which the river water is channelled to flow over greasy sheepskins which together with the perforations act as riffles to trap the grains of weathered auriferous ore as they are transported'.

The ore-laden skins have been thought to have been the origin of the legend of the Golden Fleece.

A recent suggestion is that the skins, when fully laden, were probably shaken to remove the coarse particles of gold and then hung out to dry so that the fine gold dust could be beaten out and collected (Healy, 1973). Further, Strabo says

'from the point of view of some authors, the same name was given to the Caucasian people and to the people of the far Western countrics, i.e. the name Iberians, because both regions possess gold mines'.

Strabo vividly describes Iberia as a country full of metals, a fact also commented on by Pliny, At first, gold was found in the rivers and near the surface of the ground. Later it was mined. Turdetania, after Strabo, was the richest source of good quality ore as well as Cotinae in the Sierra Morena. Gold was also obtained near the sources of the river Ebro and at Bilbilis. The rivers of Western Iberia, for example, the Tagus, were auriferous and placer deposits were frequently exploited. Indeed, in South Western Spain the legendary kingdom of Tartessos is known through historical-mythical tales. 'This kingdom is reputed to have been governed by mythical powers such as Gerion, a three headed monster, or by semi-legendary long-lived kings. Objects of gold from this mysterious culture survive. From the 7 th to the 6 th centuries B.C. is dated the rich treasure from Aliseda (Caceres) which probably comes from a woman's tomb under a barrow. It includes a fine diadem made up of articulated elements, the central part consisting of square plaques each with four circular cells decorated with rosettes in granulated wire. Rings, from which pendants are hung with short chains, are soldered to its lower band. The ends consist of triangular plaques, the borders of which carry rolled wire and four hollow soldered cabochons at the longest side. The centre is decorated with palmettes and rosettes formed by granulation. Two gold earrings each consist of a hollow tubular body on to which seven similar palmatic motifs have been soldered. Two bracelets were also found, each fabricated of two rows of joined spirals framed by three soldered wires, two of which are twisted. The soldered ends are semi-circular plates decorated with granulated palmettes. The belt plaque from this burial is famous. The central part is decorated with friezes of griffins made au repoussé, bordered by a field of granulations. The same technique is used at the ends showing a man fighting against a lion as a repeating theme. All these jewellery examples bring to mind some Etruscan goldwork of the 7 th century and certain of the items appear oriental in design. In this category are a Horus head, crescent pendants, a seal ring with a scarabee in amethyst, a gold flat cup, some silver vases and in particular a 'brasillero' and a glass bottle, which is probably a Syrian product.

Gold ornaments of the types described above have been found in tombs throughout Barbarian Europe and are essentially symbols of power and wealth related to military, religious and mythical backgrounds and procedures. Gold was also found deposited in other less evident circumstances, which could be compared with treasure offerings described by the ancient authors.

\section{Sacred Gold}

'Anincredible phenomenon is observed in celtic areas in respect of the temples of gods. In these sanctuaries these temples, which were open to everyone, contained much gold dedicated to the gods. Nobody touched it, however, because of its religious significance. The Celts loved wealth to excess' (Diodore V).

Vases were the most common type of sacred offering. A few hoards of gold vessels, dating from the 8 th century B.C. and of Bronze Age designs, have been recovered. At Villena (Alicante) a large collection of gold objects (Figure 12) which had been buried with silver and iron objects along a river was found. It included gold bracelets but consisted mainly of hammered cups decorated with repoussé bumps. In Northern Germany, in Eberswälde, $2.5 \mathrm{~kg}$ of gold cups, rings and bar ingots contained in a clay pot were discovered. A cup similar to those in these finds was also found in Zurich Altstetten, buried under a clay pot. It may have been used in a cremation. Also, in Kasitchena, near Sofia, a heavy gold cup weighing more than $1 \mathrm{~kg}$ was discovered with a bronze cauldron and a ceramic piece. Later in the Iron Age, vases of precious metals were still frequently hoarded in treasures. That they were used for drinking or making libations at funerals seems probable, for according to many ancient writers, at all sacrifices, banquets, funerals and feasts in the Hellenic world, a libation to the gods was made using a phiale. Gods and the dead are represented holding the phiale, a symbol of their own happiness and in memory of offerings. The religious use of the phiale is also indicated by the custom of leaving it at the temple after the ceremony.

Fig. 10 The treasure from Villena (Alicante, Spain). (Museo Jose Maria Soler, Villena)

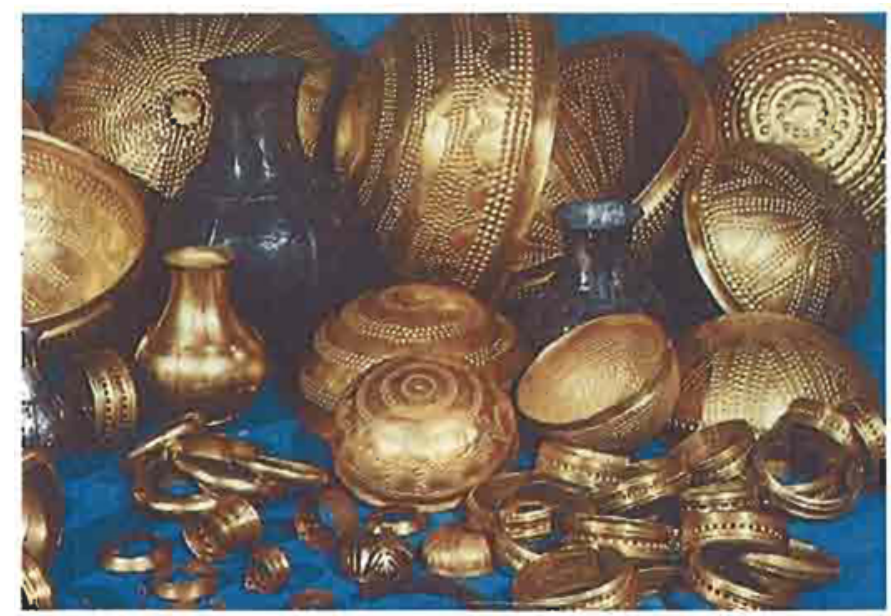


Treasuries of metallic vases were common amongst the Thracians and Dacians. Xenophon (4th century B.C.) described a banquet at King Seuthès' court, during which a Greek warrior offered oriental carpets and vases to the Thracian chieftain. Indeed, Thucidide (5th to 4th century B.C.) also said 'one cannot get anything from the Odruse without first giving precious gifts'. These gifts entiched state treasuries. Archaeological finds probably falling in this category include the rhyton in gilded silver from La Poroina Mare (4th century B.C.), and the treasure of Panagjurischte $(6.1 \mathrm{~kg})$ containing vases with a variety of forms and decorations; one phiale and eight rhytons in the form of amphora, female and animal heads. These rich vases, which are thought to have belonged to a great Thracian king, such as Seuthès III, were made by casting and soldering on protruding elements, and are thought to have come from workshops in Asia Minor, because they display a mixture of Achemenid and Greek influences.

Gold helmets constitute another category of sacred or votive offerings. From the 8 th century B.C., the Spanish gold helmet from Caudete, made in a hammered sheet with repoussé bumps, was found close to the site where the Villena cups were found. Some of these symbolic helmets were buried during the 5th century B.C. They include the Celtic helmets from Amfreville and Agris in France (Eluère, 1984) which were made of bronze or iron and decorated with gold foil. In Romania, the famous helmet au repoussé sheet gold from Cotofenesti has the same features as that from Agighiol. It is, perhaps, a representation of the sacrifice of a ram in the legend of the Golden Fleece.

'Atreus, Pelos' son, knew that the possessing of the Golden Fleece would give him power. He sacrificed a ram and hid its skin'.

At Stincesti (Romania) a gold helmet was associated with a treasure containing large gold plaques with animal designs. Some Scythian gold treasures have been buried far from their country of origin. In Vettersfeld (Brandenburg) in 1883, a Scythian gold treasure was found buried in a pot. $A$ large plaque in the form of a fish is decorated with various animals embossed among the scales of its body ( $41 \mathrm{~cm}$ length, 608.5 gram), and was probably a shield ornament with fixing loops on its internal face. Another large plaque consisting of four discs (Figure 11 (17 cm and 282.5 grams) is decorated an repoussé with animal pursuit scenes. It was secured with rivets, the holes for which were concealed under large central bosses. The find also contained a bracelet in gold, with a chain 71 $\mathrm{cm}$ in length, a scabbard, a massive ring of more than $600 \mathrm{gram}$ and an iron sword with its handle decorated with gold. This collection is probably the funeral treasury of a Scythian king.

Other relics from Scythian raids to the West are represented by several finds in Poland and especially in Hungary. In Zöldalhompuszta, an important treasure was discovered associated with indications of a cremation. The principal piece was a large gold stag made au repoussé. It was together with numerous gold buttons and a chain decorated with crouching animals.

In South-Western Europe very many jewellery treasures appear to have been used in rites. In the Iberian Peninsula, the indigenous Iron Age culture called the 'Castros' culture, which is located especially in the North Western part of the peninsula, produced gold torcs, bracelets and earrings which have frequently been found buried in fortified settlements. Unfortunately no details of the conditions of burial are available. At Herdade do Alamo (Moure, Beja) a thick sheet collar (208.4 gram) with incised and punched geometric decoration and a detachable clasp was found with other neckrings and massive composite bracelets. Both the items and their association together are typical of the Bronze Age which continued in that region. At Baiao (Porto) a treasure consisted of a diadem, a neckring and four earrings made of an impressed central part on which prepared outgrowths are soldered (Figure 12). Another example, among many others, is the treasury from Bedoia, at Grana, where a bronze cauldron contained 27 gold coins, one of Nero, others of Domitian which dates the treasure between 63 B.C. and 91 A.D. It contained also two pairs of earrings, one of the 'labyrinth' type, made of 4 superimposed pieces of gold foil soldered on a central vertical foil, and bordered by a double twisted wire. The other pair is boot-shaped with a very complex decoration of granulations.

In the south of the Iberian Peninsula, tartessian treasures are known which display very strong Eastern Mediterranean influences. The one found in the village of El Carambolo near Sevilla consists of 21 pieces weighing about $3 \mathrm{~kg}$, and includes a collar with a chain and pendants, two high cylindrical bracelets, two pectorals in the form of ox-hides and 16 belt plaques. This set is exceptionally homogeneous in that all the objects, with the exception perhaps of the neck-ring, appear to have been made by the same hand. All are made on plaques of the same thickness, one side smooth, the other covered by hemispherical soldered bumps, wires and rosettes (Figure 13). Other gold treasures reveal the luxury of life in Tartessos. At Lebrija, 6 high candelabra or perfume-burners have been found, and at Javea (Tarragone) a very thin diadem made in filigree with granulations and of the same type as the one from Aliseda was discovered. It was buried in a pot with other jewellery made of gold wire. Not far from Aliseda, at Seradilla (Caceres), a treasure discovered in 1965 contains earrings and plaques with filigree and granulations. Whether these were made locally under Eastern influence or imported remains unanswered. The same uncertainty exists in regard to the finds at Trayamar (Malaga) and Sines (South Portugal) where pendants were discovered which are very similar to Carthaginian products (Quillard, 1979).

Gold is found progressively more rarely in Celtic burials from the 4 th century B.C. onwards, and where it is encountered is frequently in the form of gold torcs. They were already familiar at this period to the Greeks and Romans who had observed them not only on Barbarians but also on Medes and Persians. Thus, Plinius and Strabo wrote about the gold torcs which were worn by the Gauls during battle. After Polybius, only some aristocratic Celtic chieftains, in the first ranks of warriors, were adorned with gold torcs. 


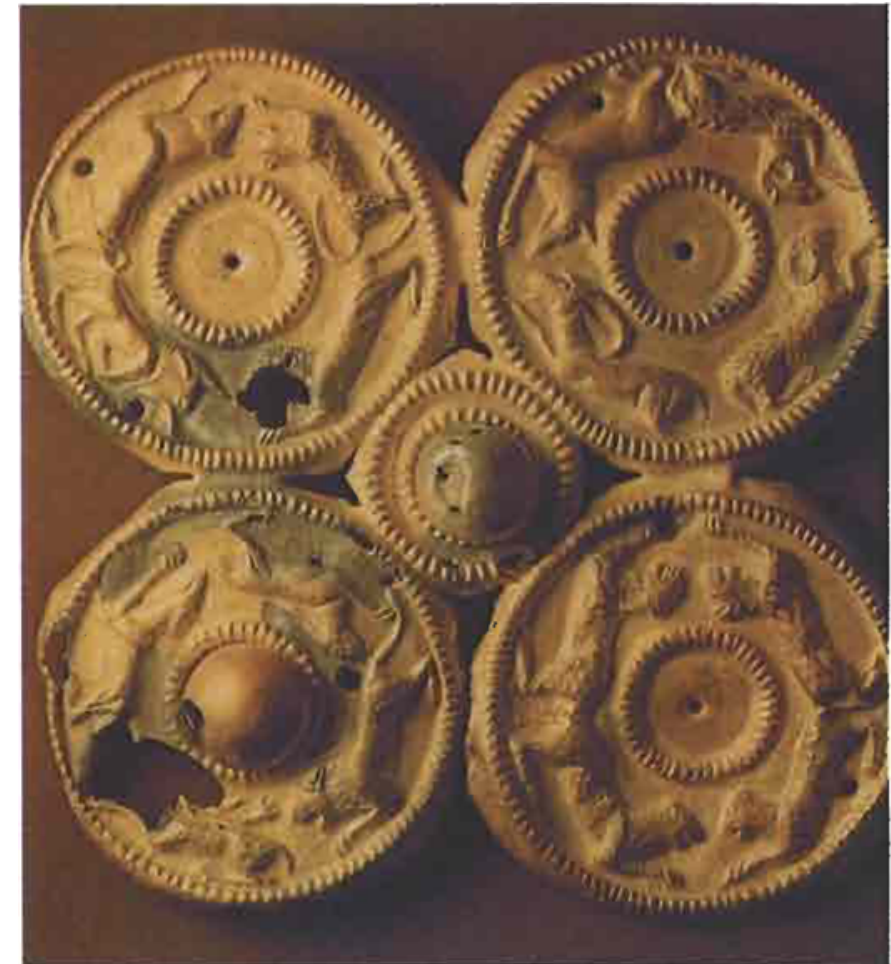

Fig, 11 Plaque from Vettenfeld (Brandenburg, DDR). (Staatliche Museum Berlin)

Fig. 12 Earring from Baiao (Porto, Portugal), of mass about 10.gr. (Museu Nacional de Arqueologia, Lisboa)

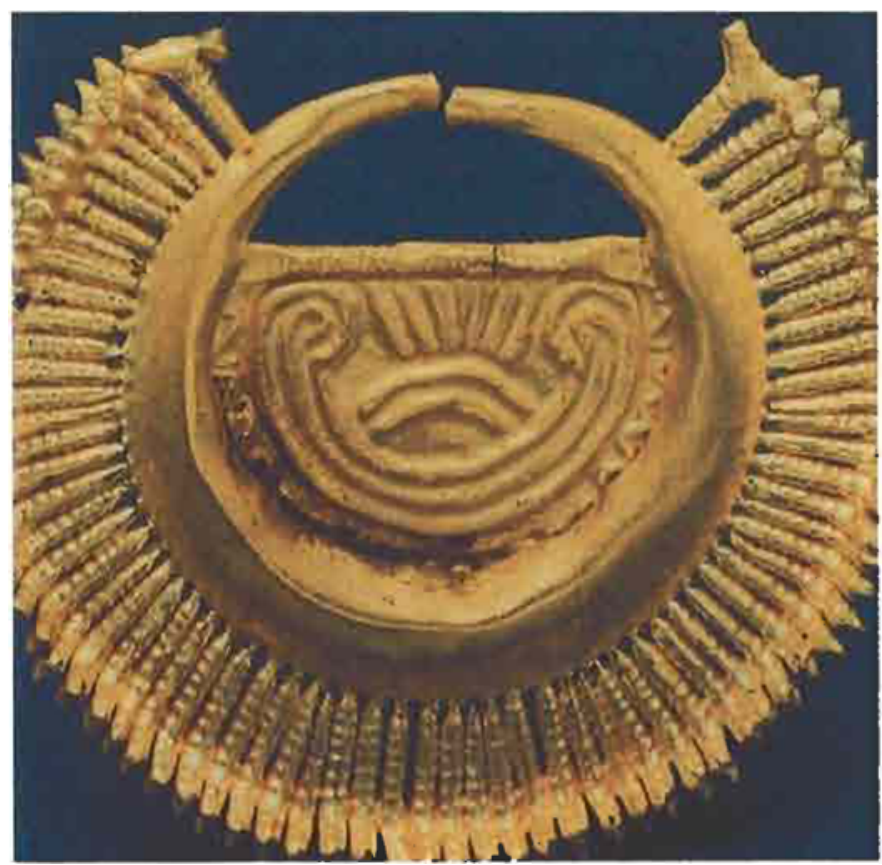

At Erstfeld in 1962 (Wyss, 1975), on the Saint-Gothard's road,

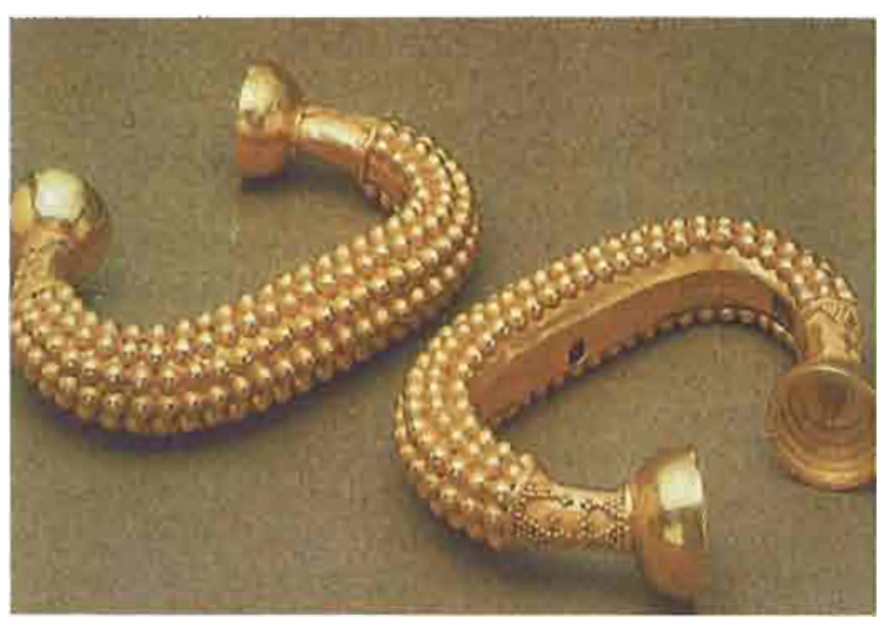

Fig. 13 Bracelets from Torre Va, Grandola (Setubal, Portugal) showing a decoration of soldered bumps similar to those on the jewels of El Carambolo; masses 192 and 187 gr. (Museu Nacional de Arqueologia, Lisboa)

a treasure hoard was discovered in the middle of the Alps which consisted of four torcs and three bracelets which date from the 4 th century B.C. The torcs are very original in design, with clusters of imaginative heads attached to a circular strip base. They were made by casting in a two-part mould, the seam of which is visible on the medial line. These torcs are not dissimilar to the rings of Reinheim. Torcs of different design and slightly later ( 3 rd to 2 nd century B.C.) manufacture are very specific to treasure hoards found in the South. West of France and may be related to the fabulous gold wealth of the Tectosages. The 6 torcs found at Fenouillet (Haute-Garonne) are differently ornamented. Five of them have very exuberant floral decoration which is fixed on a twisted bar or tube which forms the body of the jewel. At Lasgraisses (Tarn) there is such a neckring and also a bulky bracelet with a floral decoration in the internal face just hidden by the soldering of a flat gold band. Only one specimen of this type of torc has been discovered at the Eastern end of the Celtic area, in Yugoslavia at Gasic. This piece may have been carried during a migration of Celts from the South of France towards Greece and Asia Minor during the 3 rd century.

However, a recently discovered torc of this type in Bléré (Indreet-Loire) indicates that it may have had a wide distribution. This torc is now being studied in the laboratory. (C. Eluère, 'Golden Celtic Torcs', in preparation for Gold Bulletin, A. Duval, C. Eluère, et al., 1985).

Some 3rd-century B.C. Celtic gold-work has been discovered in the British Isles. In Ireland, a hoard deposited in a marsh near Clonmacnoise ( $\mathrm{Co}$. Offaly) along the Shannon river, included a torc made of two half-hoops of hollow gold tubing linked at the back by a box-like feature and at the front by a device that suggests a pair of opposed buffers. In Broighter (Co. Londonderry), in a gold hoard from the 1stcentury B.C., accompanied by a miniature boot and a long wire chain, there was a very bulky hollow torc made of a large 
curved tube decorated with repoussé and compass incised patterns. The end of the tube was slipped and riveted onto buffer ends presenting a fastening system with a hook.

In France, at Mailly-le-Camp (Aube) such a torc had been given an internal iron bar reinforcement enveloped in wax, traces of which have been identified. Its buffer ends are fitted on the tube, the joint being covered by a filigree. Torcs of this type are well dated by gold coins found with them. This was the case at Frasnes-les-Buissenal (Belgium) and at St-Louis, near Basel (Switzerland) (Furger-Gunti, 1982), where coins from the Boii, Ambiani peoples were also found. In Tayac(Figure 16), near Bordeaux, almost $4 \mathrm{~kg}$ gold was found in two clay pots. It included a torc of $758 \mathrm{gram}$, intentionally broken into five pieces, little ingots and about 500 coins (Arvernes, Ambiani, Venètes), the most recent having been struck in about 90 to 80 B.C.

After this time, gold appears to have been used for a while, without apparent purpose, mainly in the making of coins which constitute the greater portion of the last offerings of gold in the Iron Age: sacred offerings took the form more and more of money than jewellery pieces.

\section{The Classical Heritage in Barbarian Europe}

In Barbarian Europe, many gold ornaments were made by hammering the metal into bars, which were sometimes twisted, or into sheets. These basic materials were used especially during the first part of the Iron Age ( 8 th to the 5 th centuries), in the production of symbolic neckrings, bracelets, cups of the Celtic kings, vessels and masks. The hammered goldwork was often decorated with impressed motifs using techniques already known for centuries. Embossed reliefs, repoussé lines, pellets, bumps, and incised or stamped geometric designs were all used. Welding and casting were

Fig, 14 Torc and part of the hoard of Tayac (Gironde, France). Weight of the torc, $758 \mathrm{gr}$; ; the rest of the hoard consisted originally of around 500 pieces (ingots and coins). (Musée d'Aquitaine, Bordeaux)

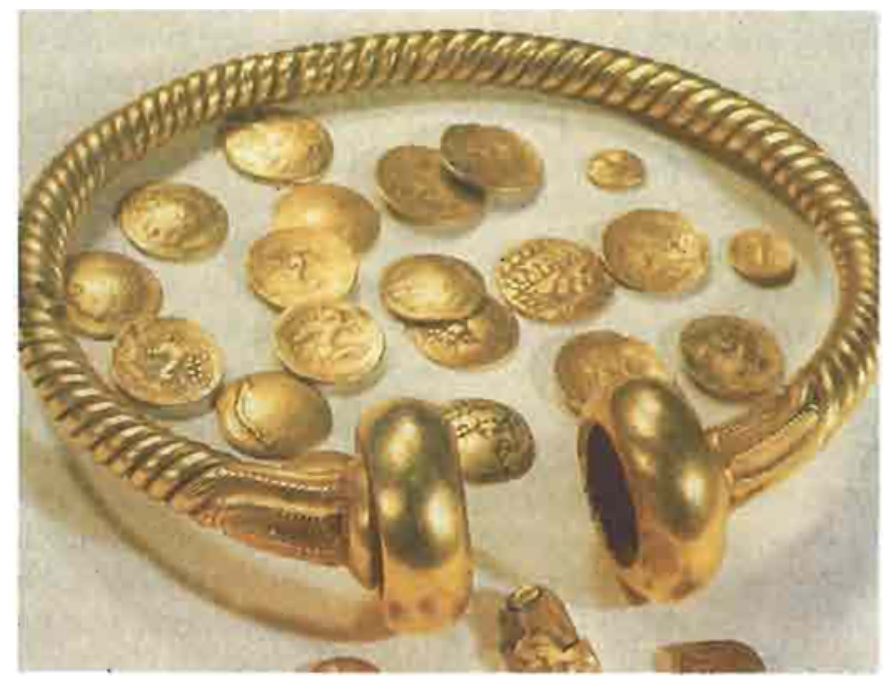

also used, as on the Sainte-Colombe earrings and the Montans torc. The products and techniques of this local barbarian technology display certain trends during the Iron Age which point - to a different degree in each area - to a possible growth of Mediterranean influence.

\section{Impressed Decorations}

The increasing use of stamped motifs and of repetitive punched patterns in Celtic jewellery of the first Iron Age and in 7 th-century Scythian plaques can be seen as part of a general tendency which is also evident in other contemporary jewellery, such as that of Rhodes, Camiros and Etruria. The numerous finds of stone dies on the Northern coast of the Black Sea, as well as the bronze die from Garcinova in Thracia (Kolkowna, 1980), prove the existence in these areas of local workshops.

\section{Cladding and Gilding}

Hammered foils were apparently applied essentially by hot pressing or riveting to numerous materials. Bronze (belt from Hochdorf, Novi Pazar), leather (shoes from Hochdorf, Trebenischte) and iron (horn from Hochdorf, helmet from Amfreville, plaque from Weiskirchen, as well as the armour of Philip of Macedonia were all used as substrates, but to an increasing extent the material which was clad with gold was silver (phiale of Vix, Cotofenesti helmet, the cnemid of Wraza). Curiously also, silver both in gilded and ungilded form tended to replace gold from the 3 rd century onwards in the zones most subject to Hellenic influence such as Iberia, Thracia and Dacia (treasures of Galitsche, Tibissa). Casting, Fitting and Soldering Composite Products

Celtic torcs decorated with imaginative semi-human heads were made either by casting the separate elements (Erstfeld) or making them au repoussé (tubular torc of Frasnes-les-Buissenal). Sometimes the terminals were cast apart and afterwards joined to the body by pressing (Montans). Sometimes they were cast directly over the body (Snettisham, Ipswich) or soldered on it (Bléré). The Kul'Oba torc has ends in the form of horsemen which were separately cast and soldered on. Some jewellery was made of several soldered pieces, for example the Vix torc, the Tolstaia Mogila torc, and the Solokha peign. On these pieces it seems possible that a metal braze was added in forming the joints, but unfortunately analytical evidence of this is lacking. However, soldering is a technique which appears to have been introduced mainly by the goldsmiths of the First Iron Age, as shown by some of the earliest examples (ears of the Kelermes panther, bondings at the back of the Scythian plaques, or ends of bracelets, and ends and decoration of the earrings at Ste-Colombe). These solderings probably were made by simple heat treatment. Thus an examination of such a joint on a neckring fragment dating from the First Iron Age from Eastern France using X-ray microfluorescence and SEM did not reveal any variation in composition over the joint area, while the later Celtic torc from Bléré had soldered ends, in which additional copper was 
present.

\section{New Figurative Iconography}

There were no human and very few animal figures in Barbarian goldwork before the Iron Age. Among the earliest examples is a frieze of little punched human masks on a Celtic neckring fragment from Eastern France and some beads, from the Hungarian hoard at Szarad Regöly, on which such masks are soldered. The theme of the horseman is present at Hochdorf, and also on a plaque from Ribzdea (Spain), the helmets from Cotofenesti and Agighiol with the apotropaic eyes, also on the Scythian neckring from Kul'Oba. Warriors' figures feature on the Solokha peign and on different plaques and vessels from Kul'Oba and Solokha, and peasants on the Tolstaia Mogila pectoral. A semi-human head is frequently stamped on little Celtic foils (as at Schwarzenbach) used for cladding. Such imaginative heads appear also on torcs of bronze as well as of gold. Animal figures are also stamped or punched and patterned on Scythian pieces, a frieze of ducks is punched on the Spanish plaque from Crevillente, and a granulated duck decorates each end of the Vilas Boas torc. Horses and griffins are found on the Tolstaia Mogila torcs, while winged horses decorate the Vix one. These animal themes are closer to the Oriental world and are found on Thracian rhytons, on which sphinxes; horses and stagheads all occur. Certain themes such as fights between animals and fights between men and animals (Aliseda), are possibly inspired from Asia Minor, or from Greek mythology (Gorgona on the Wraza cnemid, Athena on the Kul'Oba pendants, Aphrodit on the Wraza cup, Dyonisos scenes on Thracian vases).

Like the human and animal decorations, the floral or plant patterns appear in a very stylized form in the Barbarian goldwork. Lotus blooms on Celtic openwork at Schwarzenbach, for example, and at Eygenbilsen, while at A liseda, or Sines, the plant motifs are more realistic. Rosettes appear on the Tolstaia Mogila pectoral, and pendants from Wraza.

Decorative Mediterranean Patterns: Chains, Filigree, Granulations, Bedded Wires and Incrustations, Gold Coins

Chains made with the loop-in-loop system are found in Thracia, on the Wraza pendants in Spain at Seradilla. Double loop-in-loop is present in the Broighter hoard and in the pendants of Kul'Oba in the Celtic tomb at Ins (Switzerland) while triple loop-in-loop exists in El Carambolo.

Filigree work and granulation were frequent in Thracia. In Duwanli tombs, both earrings and pendants have granulations which together with filigree are present on the Wraza pendants and on Kul'Oba jewellery. Filigree appears on the Kul'Oba torc as well as on the pectoral of Tolstaia Mogila, which shows also numerous beaded wires and a chain.

All of these techniques were abundantly used in the Iberian Peninsula, at Aliseda, Javea, Seradilla and Trayamar, the jewellery from all these places reflecting Mediterranean influence.
They are rarely found, however, in the Western Celtic area. Only two objects carry filigree and granulation. Found at Jegensdorf and Ins in Switzerland they are considered as Etruscan imports. Their composition seems to justify this hypothesis. Filigree with some granulation, used together with a repoussé imitation of beaded wire on the torc of Mailly-le-Camp, is one of the rare examples of that area. However, in the Oriental Celtic area, Mediterranean influence emanated from the Black Sea and both filigree and granulation are present on a typical tubular Celtic torc with buffer ends, found in Hungary, and now in the Budapest museum, and also on beadsand pendants from the Szarad Regôly hoard(Szabo, 1975). Beaded wires in wandering patterns decorate the Vix torc, and a neckring at Broighter and seem to have been widely used. In general, in the Celtic area, there are very free imitations of them made either by repoussé or stamped techniques from the inside of sheets or foils (Schwarzenbach), or cast and eventually eng raved afterwards with a chisel, from the outside. It is more difficult to consider repoussé pellets or dots as imitations of granulation, because they appeared very early during the Bronze Age.

Thus there appears to have been little importation of Mediterranean goldwork into Celtic countries which also showed little acceptance of the cultures from those areas although the Celts did trade with them. Examples are limited to some filigree, beaded wires. Imitations of such goldwork appear to have been more common, and clad, hot soldered and filigree work already existed at the very end of the Bronze Age in Ireland (Eluère, 1983). It is surprising however, that the highly developed Etruscan goldwork is not found more frequently in centres where so many rich bronze vessels of Etruscan origin have been discovered. Apparently, goldwork was not used in bartering and trade, perhaps because of its prestigious and personal nature, so that little Etruscan influence in Celtic gold work is evident. Even the Hellenic-influenced South of France has yielded practically no goldwork (one bracelet in a tomb from the Languedoc, and a strip with filigree in a cave in the Aude region). The most important development affecting their use of gold which reached Western Celtic countries was the minting of gold coins by Philip of Macedonia. These provoked the local production of gold coins in Gaul.

In the North and West of the Iberian Peninsula, the Castros culture seems to have developed local traditions and also introduced Mediterranean techniques, like granulation and filigree work, though this could have appeared in earlier Bronze Age culture contexts, as in Ireland. On the Southern coast, the goldwork clearly belongs to the Mediterranean area, and, in particular, the proportions of silver and copper in gold objects from Aliseda, Carambolo and Javea are quite different from other objects from the continental Celtic area, being related on the other hand to the traditional goldwork, like in Villena, or the Castros hoards from Baiao, Vilas Boas.

Around the Black Sea the numerous metal or goldsmith workshops at Panticapée, Olbia, Chersonèse, on the Northern coast, 
or at Pecica, in the West, as well as the numerous punches and dies found in Thracia (Kolkowna, 1980) leave no doubt that local goldsmiths were active in these areas. But were they Greeks, Scythians or Thracians? The question is still unanswered. Since Greece was far less rich in gold than Thracia, Macedonia and Scythia, it is very possible that goldsmithing in these areas was a traditional craft, which was used to supply demands from Greece. Moreover, the earliest goldwork from this region has definite local characteristics. These include a high proportion of copper in the metal used. In Scythian plaques this may reach 10 to 30 per cent for 1 to 6 per cent silver, according to a few analyses published by Kulkova (Mohen, 1975). A short note describing the compositions of

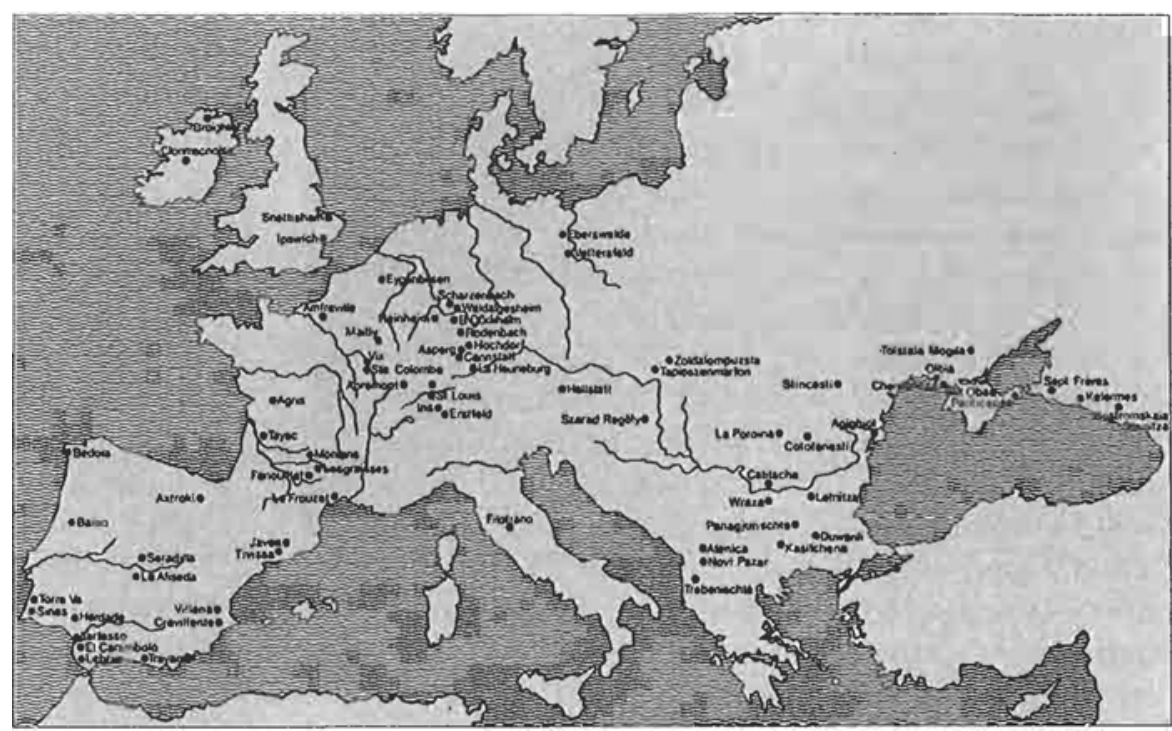

Geographical locatıon of principal finds cited the various gold finds cited in this article will be published in a forthcoming issue of this journal.

\section{Concluding Remarks}

The classical contribution to the art of goldworking in most Barbarian countries in Europe appears at this stage to have been strictly limited. Barbarian goldsmiths certainly learned from the work of their classical counterparts, but what they learned supplemented and modified their own craft, rather than fundamentally changing it.

One is left with the impression that Mediterranean peoples were as fascinated with Barbarian goldwork as the Barbarians were by the products of the Mediterranean area.

'The Tarbelli found slabs of gold as big as the hand could hold' (Strabo, IV).

\section{General publications:}

M. Almagro Gorbea, 1977. El Bronce Final y el periodo orientalizante en Extramadura, Madrid. Bibliotheca Prae historica Hispana, XIV, 554 pp., $78 \mathrm{pl}$.

K. Bittel, W. Kimmig and S. Schieck, 1981. Die Kelten in Baden Wikttemberg, Stuttgart, 533 pp., 438 ill.

F.L. Cuevillas, 1951. Las Joias castrenas, Madrid, 123 pp. ill.

P.M. Duval, 1977. Les Celtes, Univers des Formes, Paris, 325 pp. 447 fig.

A. Hartmann, 1970 and 1982. Goldfunde aus Europa, S.A.M.

J.F. Healy, 1978. Mining and Metallurgy in the Greek and Roman World, London, 316 pp. ill.

J.V.S. Megaw, 1970. Art of the Eumpean Iron Age, 195 pp., $306 \mathrm{fig}$.

J.P. Mohen, 1975. Le travail de l'or au pays des Scythes et en Sibérie, Revue du Lozvre, Paris, pp. 305-311, 9 fig.

J. Ogden, 1982. Jewellery of the Ancient WOrld. $185 \mathrm{pp}$.

B.A. Outeirino, 1982. De ouriveseria castrexa, Arracadas, Boletin Avriense, Annexo $1,608 \mathrm{pp} ., 50 \mathrm{pl}$.

Catalogues of exhibitions:

- The Illyrians and Dacians, Belgrade 1971

- Ordes Scythes, Paris, 1975, 225 pp., ill.

- Magisches Gold, Nürnberg, 1977, 114 Pp. ill.

- Gold der Tbraker, Mainz, 1979, 240 Pp, ill.

- Trésors d'Irlande, Paris, 1982, 256 pp. ill.

- Lart celtique en Gaule. Paris, 1983, 219 pp. ill.

- Los Lberos, Madrid, 1983, 200 pp.

Articles on specific subjects:

J. Biel, 1982. 'Ein Fürstengrabhügel der späten Hallstattzeit bei EgerdingenHochdorf, Kr. Ludwigsburg, Baden-Württemberg', Germania, 1982, pp. 62-104, 30 fig.

\section{Bibliography}

R. Cesaero and F.W. Von Hase, 1973. 'Non Destructive Radioisotope XRF Analysis of Early Etruscan Gold Objects', Kermtechnik, 1973, 12, pp. 565-569, fig.

A. Duval and C. Eluère, et al, 1985. 'Le torque de Blëré (Indre-et-Loire)', Revze du Louvre (in press)

C. Eluère, 1983. 'Prehistoric goldwork in Western Europe', Gold Bull, 1983, 16, pP $82-91,15 \mathrm{fig}$.

C. Eluère, 1984. 'Two unique golden heImets', Gold Bull, 1984, 17, pp. 110-111 A. Fürger-Gunti, 1982. 'Der Goldfund von Saint-Louis bei Basel und ähnliche keltische Schatzfunde', Zeitscbr. firr Archäol. und Kunstgesch., Basel 1982, 39, pp. 1-47, ill.

R. Joffroy, 1954. 'La tombe de Vix', Monumentset Mémoires, Fondation Piot, 1954, 48

S. Kolkowna, 1980. 'Outils d'orfevre au Nord et à l'Ouest de la Mer Noire, Aurifex 1, Louvain, pp. 106-153, 27 pl., 1980

T.F. Kulkova, 1962. Mikrochemische Untersuchung von Goldgegenständen, nevie Methoden der archöologischen Forschung, Moscou-Leningrad, Pp. 86-90 (in ROUDENKO, Sibirskaia kollektia Petra I, (S.A.I.), 1962

A. Mantsevitch, 1980. 'Origine des objets de toreutique d'époque scythe', Aurifex

1, Louvain, pp. 80-105, 18 fig., 1980

D. Mano-Zisi and L.B. Popovic, 1969, Novi Pazar, 1844-1969, Beograd, 1969

L.B. Popovic, 1956. 'Katalog Nalazoiz nekropole Ko'Trebenista'. Antika 1, Beograd, 1956

B. Quillard, 1979. 'Bijoux Carthaginois, les colliers', Aurifex 2, Louvain, 125 pp., 19 pl., 1979

M. Szabo, 1975. 'Sur la question du filigrane dans l'art des Celtes orientaux', Alba Regia, pp. 147-165, X pl., 1975

R. Wyss, 1975. 'Der Schatzfund von Erstfeld', Arcbäol., Forsch., Zurich, 68 pp., 23 fig., 8 pl., 1975 